\title{
SAD but True: Species Awareness Disparity in Bees Is a Result of Bee-Less Biology Lessons in Germany
}

\author{
Laura Christ * and Daniel C. Dreesmann (D)
}

Citation: Christ, L.; Dreesmann, D.C. SAD but True: Species Awareness Disparity in Bees Is a Result of Bee-Less Biology Lessons in Germany. Sustainability 2022, 14, 2604 https://doi.org/10.3390/su14052604

Academic Editor: Alejandro Rescia

Received: 17 December 2021

Accepted: 22 February 2022

Published: 23 February 2022

Publisher's Note: MDPI stays neutral with regard to jurisdictional claims in published maps and institutional affiliations.

Copyright: () 2022 by the authors Licensee MDPI, Basel, Switzerland. This article is an open access article distributed under the terms and conditions of the Creative Commons Attribution (CC BY) license (https:/ / creativecommons.org/licenses/by/ $4.0 /)$.

\author{
Department of Biology Education, Institute of Organismic and Molecular Evolution, Johannes Gutenberg \\ University Mainz, D-5099 Mainz, Germany; daniel.dreesmann@uni-mainz.de \\ * Correspondence: laura.christ@uni-mainz.de
}

\begin{abstract}
Bee and insect mortality has recently moved to the forefront of current nature conservation debates and experiences intensive media coverage worldwide. In order to understand the complexity, it is necessary to raise awareness of the diversity of bees. This study investigated whether students are aware of the species diversity of bees. We are guided by the concept of 'plant blindness' and show that it cannot be assumed that people are only 'plant-blind'. Therefore, we introduce the concept of Species Awareness Disparity (SAD) in bees to describe a phenomenon which can be defined as the failure to appreciate the significance of wild bee species and the inability to distinguish between individual species of the Apidae family. A total of 421 German students in grades 5-7 participated. The majority of students did not associate a diversity of species with the term 'wild bee' but rather consider the honeybee as the bee. Only $2.7 \%(\mathrm{~N}=421)$ of the students were able to correctly identify pictures of wild bees and the honeybee. This highlights the importance of educating students about the identity and nature of bees in their environment so that they become aware of their meaning from both a personal and an ecological perspective.
\end{abstract}

Keywords: bees; awareness; biodiversity; environmental education; conservation

\section{Introduction}

There is broad scientific evidence of an ongoing decline of many insect species in Europe, North America, and other regions of world [1]. Although differences have been reported related to taxonomic lineages and rates of decline, studies predict annual species losses up to 10 percent for some terrestrial regions and Europe being more affected than other parts of the world [2]. As reviewed by Sánchez-Bayo and Wyckhuys, numerous studies exclusively list anthropogenic factors as drivers of insect decline [1,3]. Here, both climate change and losses of intact habitats due to urbanization and intensive agriculture are considered to contribute to shifts and losses of ecosystem functions. As a consequence, this worldwide decline in the number of insect species has elicited considerable public attention $[4,5]$. The loss of bees as important pollinators for both wild and crop plants has especially led to concern [4] and even to public protests, e.g., in Germany, where our study was conducted. Accordingly, a referendum with the title 'Petition for Species Diversity: Save the Bees' was enforced in one federal state, while similar petitions are discussed in other federal states of Germany [6]. However, the loss of species diversity is not the only problem. In addition, the absolute number of insects is also radically declining considering their biomass per area [5].

\subsection{Economic and Ecologic Value of Bees and Loss of Insect Biodiversity}

The consequences of diversity loss are both ecological and economic. Seventy percent of the 124 most valuable crops for human consumption rely on bees as pollinators [7]. The annual value of insect pollination in the EU is 14.6 billion EUR, which represents $12 \%$ of the total economic value of annual crop production [8]. Next to the economic importance, 
the ecological consequences are no less serious: Insects occupy important niches in various ecosystems and thus ensure their stability [7,9]. Pollinating insects also play a crucial role with regard to the biodiversity of flowering plants: High species diversity of pollinators promotes high species diversity of plants and vice versa [10]. The more species there are, the less impact external disruptions and changes may have. This is mainly due to the fact that a mutual adaptation between pollinators and plants has co-evolved over time, leading both to oligolectic bee species which forage for pollen on just a narrow variety of plant species and polylectic species with a broad foraging spectrum [11]. Given the fact that about $30 \%$ of Central European solitary bee species are oligolectic [12], an ongoing demand for more bee-specific conservation efforts is justified.

The western honeybee Apis mellifera, whose large colonies pollinate big areas of crops and at the same time provide honey for human consumption, is the most common managed pollinator of wild and cultivated plants worldwide [13]. Nevertheless, the number of managed honeybee stocks have also declined and the well-documented death of thousands of honeybee colonies, for example in Europe and North America, is alarming [14]. Although most media coverage regarding pollination focuses on honeybees and many people are oblivious of the importance of other bee species [15], experts have been pointing at wild pollinators such as bumblebees and solitary bees and their fundamental roles in food production and ecosystem integrity $[16,17]$. They provide a global value of approximately 153 billion US dollars through their pollination services [18,19], making them efficient pollinators of crops beside the honeybee $[7,20,21]$. However, the species richness of wild bees and other pollinators has declined over the past 50 years and some species have even become extinct. As bees in general account for one third of flower pollinators and wild bees provide at least $20 \%$ of pollination services in agronomy, reported declines show strong negative effects [3]. In Germany, according to the Red List of Apidae, $47.7 \%$ of bee species are extinct or threatened with extinction, while $37 \%$ are not at risk [22].

\subsection{A Bee or Not a Bee? A Matter of Language}

To be able to imagine and assess the extent of the loss of bees described above, it is important that people not only associate honeybees with the word 'bee' but also consider wild bee species. In everyday language, we mainly talk about bees and do not distinguish between species within the Apidae family. Moreover, for the general public, bees are synonymous with honeybees whose fate is closely followed due to their role not only as pollinators but especially as honey and beeswax producers [23].

Bees are a monophyletic lineage within the superfamily Apoidea. The largest family within Apoidea is Apidae, which contains over 6000 species. Among them are the western honeybee Apis mellifera, which is one of the first domesticated insect species and hence considered by the general public as the honeybee, and bumblebees within the genus Bombus [24]. The German word for bee is 'Biene' whereas a bumblebee is named 'Hummel'. Unlike in the English language, the German words for bee and bumblebee have no common ground. This is the case for many Western languages. Within Germanic languages, only Danish speakers will associate a 'humlebi' (i.e., bumblebee) with a 'bi' (i.e., bee) while words are different in Swedish ('humla' vs. 'bi'), Norwegian ('humle' vs.'bie'), and Dutch ('hommel' vs. 'bij'). Romanic languages show a similar pattern where in Spanish 'abejorro' (i.e., bumblebee) is derived from 'abeja' (i.e., bee). Speakers of French, Italian, and Portuguese, however, use different words ('bourdon' vs. 'abeille'; 'calabrone' vs. 'ape'; 'zangão' vs. "abelha". Interestingly, in many languages including German, the word for bumblebee ('Hummel') derives from the buzzing sound of flying bumblebees [25] (p. 1880); [26] (p.748); [27] (p.429). Likewise in English, the word 'bumble' relates to the humming sound that bumblebees make.

To distinguish other representatives of bees, including bumblebees, from honeybees, the German word 'Wildbiene' - literally 'wild bee' — was coined. It is used in everyday life even though it is not a scientific term of taxonomic relevance. 'Wild bees' comprise all species beside honeybees of the superfamily Apoidea within the order Hymenoptera [28]. 
In English, bee species other than bumblebees and honeybees are commonly referred to as 'solitary bees' due to their life cycles.

\subsection{From 'Species Diversity Blindness' to 'Species Awareness Disparity' for Bees}

Knowledge about the diversity of living organisms is a crucial factor in recognizing the need for protection and as a consequence implementing appropriate conservation measures in our everyday life. This holds true for both solitary bees and 'wild bees' which are by far the largest taxonomic group worldwide [14]. In Europe, one can find almost 2000 bee species, and in Germany more than 566 bee species are listed [29]. The different species show an enormous variety in shape and appearance: Besides typically black and yellow colored species, there are also red-banded, white-spotted, or blue-shimmering species, which can be either furry or hairless [12].

Due to a lack of knowledge, the diversity of living organisms is systematically overlooked in everyday life. A now well-known phenomenon that describes people's inability to see individual species in their environment has been established for plants and is called 'Plant Blindness'. The term was initially described in 1999 by Wandersee and Schussler as "the inability to see or notice the plants in one's environment-leading to (a) the inability to recognize the importance of plants in the biosphere and in human affairs; (b) the inability to appreciate the aesthetic and unique biological features of the life forms belonging to the Plant Kingdom; and (c) the misguided, anthropocentric ranking of plants as inferior to animals, leading to the erroneous conclusion that they are unworthy of human consideration" [30].

Here, aspect (a) includes the importance of pollination of plants, which has been neglected as an indispensable ecosystem service, and can be specified as 'pollination blindness' [31].

Plant blindness is influenced by several factors: attention, attitude, knowledge, and relative interest [32]. Most people do not pay attention to plants in their daily lives [33]. The reason for this may be that the human brain looks for visual stimuli to distinguish objects from each other [34]. However, attitude also has an influence on the perception of plants as long as many people are convinced that plants do not matter to humans [32]. The knowledge component describes a more specific knowledge about plants and appreciation for why plants are invaluable to the biosphere and human affairs [32]. In addition, people find other organisms, especially animals, more interesting than plants and therefore pay more attention to them which is part of the factor 'relative interest'. Since the term 'blindness' can give the impression that it is merely a matter of not seeing things, Parsley [32] proposes to speak of plant awareness disparity (PAD) instead: "PAD emphasizes that plants are not completely unseen, but rather placed in the background in the visual service of noticing other organisms" [32]. In addition, Parsley [32] raises concerns that the term 'blindness' hurts people from the disabled community and thus contributes to ableism.

However, the phenomenon not only applies to plants, but it is also evident with other organisms. Knapp [35] speaks of humans being "everything-but-vertebrates blind". As it cannot be assumed that all animals are perceived equally and draw more attention than plants, a distinction should also be made between different animal species. People tend to like large, intelligent animals with the capacity for social bonding [36]. In contrast, they tend to encounter invertebrate species with rejection and evaluate them more negatively than vertebrates $[37,38]$. A difference in interest between mammals and insects has also been found in school contexts. Urhahne et al. [39] not only showed that the general interest in insects and mammals decreases from grades 5 to $8 / 9$, but they also found that mammals generate higher interest than insects across grades. Therefore, it can also be assumed that the diversity of insect species is not perceived in everyday life and that attitudes and a lack of knowledge can have an influence on the willingness to protect. For this reason, we initially focused on the term 'Species Diversity Blindness' with regard to bees as pollinators. With reference to Wandersee and Schussler [30], it reflects the inability to see or notice bees other than honeybees in one's environment, thereby neglecting their importance for biodiversity. However, this initial concept may fall short for a number of reasons: People use daily newspapers and magazines as sources of information about 
topics like biodiversity [40]. It can therefore be assumed that media coverage influences the perception of bees in one's environment and that it frames conservation issues. In addition, insect pollinator conservation is a hot topic in global media, but the focus is mainly on honeybees $[14,17]$. On the other hand, school education plays a crucial role for the promotion of both species knowledge and understanding of ecological concepts. For example, hands-on opportunities which demonstrate how plants and insects interact can influence attitudes in a positive manner [41]. Furthermore, as species identification is the basis for biodiversity conservation, it is important to counteract plant and species diversity blindness [42].

Following Parsley's arguments [32] as well as Silveira et al. [43], we introduce the concept of 'Species Awareness Disparity' (SAD) for bees in order to describe a phenomenon which can be defined as the failure to appreciate the significance of wild bee species and the inability to distinguish between individual species of the Apidae family. Although speaking of 'blindness' is straightforward in typical situations where plants are not perceived in the presence of animals (e.g., the tree whose branch is used as a perch by a feeding bird), we opted against using 'blindness' in this context. As it is general knowledge that bees, i.e., honeybees, can sting, a certain amount of fear is associated with their appearance. Hence, most people are not 'bee blind' when it comes to close encounters with bees or even wasps. Like PAD, SAD is represented by a combination of attention, attitude, knowledge, and relative interest as categories which can be addressed both individually and in combination. We will elaborate on SAD in an educational setting of a research project which aims at promoting knowledge of the role of bees in conservation through an original encounter with solitary bees and bumblebees, in particular, as 'ambassador species'. The concept of ambassador or flagship species has been established in the context of conservation marketing where it is assumed that public perception of endangered species precedes awareness and the willingness to engage [44,45]. Main characteristics of an ambassador species are both their popularity as a starting point to stimulate conservation awareness as well as action and their ability to raise attention for biodiversity and conservation issues [44].

\subsection{Lack of Bee Biodiversity in the Biology Classroom-A Promotor of SAD?}

Promoting biological knowledge to children and young adolescents is anchored in the context of school education. From an educational point of view, it is therefore useful to determine students' state of knowledge and possible misconceptions in order to support biology teachers in their selection of teaching content. The biology curriculum is very open in many federal states of Germany. Teachers are required to teach the necessity of biodiversity for the stability of an ecosystem, but they can decide for themselves which species to use in the classroom [46].

However, the choice of teaching material which is available to teachers in this field is very limited, as German textbooks and corresponding teacher guides often focus on the honeybee to demonstrate the morphology of insects and the role of pollinators for an ecosystem's stability and agricultural productivity. Regardless of the choice of organism, it is important to distinguish between scientific and colloquial language in order to prevent a one-sided understanding of the word 'bee' as honeybee and to avoid confusion [47].

In contrast, other pollinating insects such as bumblebees are strongly underrepresented in German school textbooks and rarely covered in class [48-50]. Batke et al. [51] showed that the underrepresentation of plant-related curriculum content in schools has some influence on plant blindness, so it can be inferred that this may also apply to species diversity blindness.

This is not conducive to an approach to insects and topics such as environmental education and conservation because insects have been associated with fear and dislike in previous studies [52-54] and bees in particular have been associated with fear [55,56] bumblebees on the other hand, students have a positive attitude [57]. This could have considerable potential for increasing knowledge in the field of "wild bees" and insects. 
In a previous study, we examined the relationship between pro-environmental behavior intentions and knowledge, attitude, fear, interest, and learning enjoyment in a school intervention involving hands-on activities with living bumblebees. High interest in bumblebees led to a high willingness to implement bumblebee-friendly, pro-environmental behavior intentions which correlated highly with attitude and interest [58]. Due to the overall importance of 'wild bees' mentioned above, the study presented here addresses German high school students' associations and identification skills regarding 'bees' in general. Our study participants from three grade levels were selected to represent children at the beginning of their biological education (5th and 6th graders) as well as young adolescents (7th graders) whose curricula address insect biology and insect biodiversity in particular.

Our study aim was to address the SAD categories of knowledge and attitude as an empirical proof of concept. The two remaining categories, attention and relative interest, are closely related and may allow indirect conclusions. They will be addressed more thoroughly in a different research context.

The specific research questions were:

(1) What do children and young adolescents associate with the term 'wild bee'?

(2) Are children and young adolescents aware of species diversity in 'wild bees'?

(3) Are children and young adolescents capable of differentiating honeybees from other wild bees and insects?

\section{Materials and Methods}

Our study was conducted within an educational project which focuses on bumblebees as ambassador species to address insect decline in high school biology classes. In our paper-pencil survey, which was conducted from April to July 2021, a questionnaire was completed by $\mathrm{N}=421$ students. Participating students came from 10 different schools and three different class levels within the German three-tier school system implemented after the 4th grade. Our study sample was compiled by directly approaching schools in the context of implementing a new educational project. Participating teachers were asked to supervise the survey according to our instructions. All participating schools were located within the metropolitan area of the Rhine-Main region in Germany (Table 1).

Table 1. Descriptive statistics of study sample.

\begin{tabular}{cccc}
\hline & 5th Grade & 6th Grade & 7th Grade \\
\hline Female & 52 & 46 & 84 \\
Male & 64 & 25 & 117 \\
No indication of & 1 & 0 & 6 \\
gender & $11-12$ years & $12-13$ years & $13-14$ years \\
Age & 117 & 71 & 207 \\
Total & &
\end{tabular}

In total, 182 female, 206 male, and seven students with no indication of gender took part in the survey. They had not received any preparation in the form of special teaching units. As not all participants stated their gender, the total number of students differs from the sum of males, females, and no indication of gender. All participants completed the survey voluntarily and independently during class. Students were asked not to cheat and to fill out the questionnaire carefully, knowing that the survey would not influence their grades. Approval by state school authorities was granted in advance.

\subsection{Questionnaire}

We focused on the association, i.e., mental connection, of wild bees and the ability to recognize bee diversity. In an open-ended task, students were first asked to describe what came into their minds when hearing or reading the word 'Wildbiene'. On the basis of their responses, we classified students into the following seven categories: honeybee, conservation, environment, insects, positive feelings, negative feelings, and value. 
Next, participants were presented with color photographs of honeybees, hoverflies, and a set of bee species. Overall, participants were shown two pictures of honeybees, seven pictures of other bee species, and three pictures of hoverflies (Figure 1).

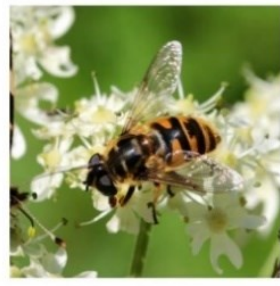

Episyrphus spec.

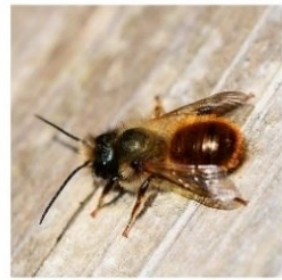

Osmia bicornis

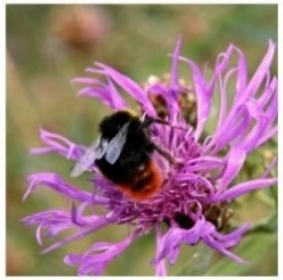

Bombus lapidarius

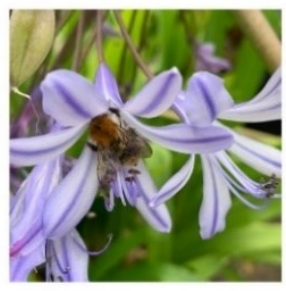

Bombus pascuorum

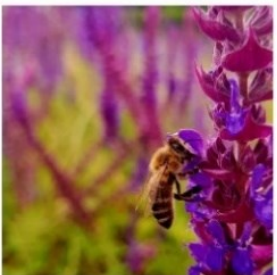

Apis mellifera

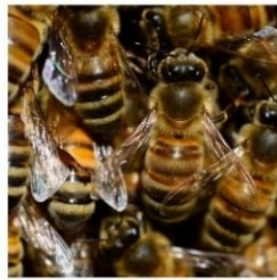

Apis mellifera

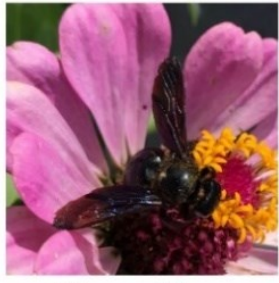

Xylocopa violacea

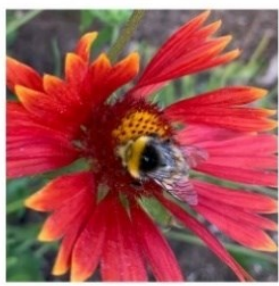

Bombus hortorum

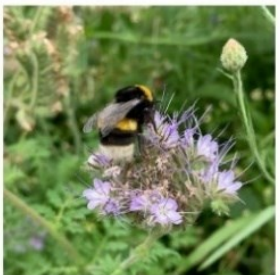

Bombus terrestris

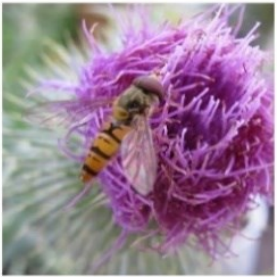

Episyrphus spec.

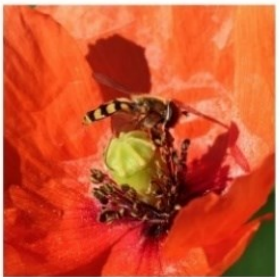

Episyrphus spec.

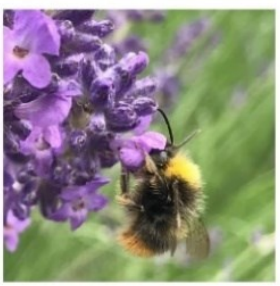

Bombus pratorum

Figure 1. Pictures of species for the identification task of wild bees. Insects were photographed from above so that they were fully visible.

Consulting widely used field guides [59,60] and a recent monograph [29], common species found in private gardens, public parks, and natural environments were chosen. Hoverflies, which are common in Germany and as mimics resemble bees although they belong to the insect order Diptera, were chosen as distractors. In an identification (ID) task, students were asked to indicate whether the pictures showed a wild bee or not. Response options were 'Yes', 'No', and 'Don't know', the latter being offered in order to minimize lucky or educated guesses being made. Based upon correct answers, we calculated ID scores by assigning zero points for wrong answers and 'Don't know' and one point for a correct identification. Thus, participants could obtain ID scores ranging from zero to 12 .

\subsection{Data Analysis}

Different sets of data were analyzed using IBM SPSS 27.0 following Field [61]. As our data are not normally distributed, we applied non-parametric tests for category assignments and ID scores as well as descriptive statistics for additional data analyses. Normal distribution of ID scores was assessed by the Komolgorov-Smirnov test and the ShapiroWilk test; the Mann-Whitney $U$ test was subsequently calculated for gender differences. 
For the category assignment task, gender differences were analyzed with the chi-square goodness of fit test.

\section{Results}

To evaluate the results of the open-ended task, students' answers concerning their associations with the term 'wild bee' were classified into seven categories. When asked about what came into their minds when hearing or reading the word 'Wildbiene', 76\% of our study sample gave at least one answer. Students $(\mathrm{N}=320)$ most frequently mentioned terms such as 'honey', 'honeybee', or 'hive' that were attributed to the category honeybee. This category also includes terms like 'honey and fear', 'honey and bee decline', 'honey and flowers', 'honey, bees, flowers, hive', and 'buzzing, flowers, and honey'. Second in order of mentions were words which are included into the category environment (Table 2).

Table 2. Mean scores of associations with the term 'wild bee' in seven categories $(\mathrm{N}=320)$.

\begin{tabular}{ccc}
\hline Category & Examples & Naming (\%) \\
\hline honeybee & 'honey'; 'honeybee'; 'hive' & 28.1 \\
conservation & 'flowers and conservation'; & 10.9 \\
environment & 'decline of insects'; 'threat' \\
insects & 'environment'; 'flowers'; 'forest' & 20.0 \\
positive feelings & 'busy bees'; 'insects'; 'wasps' & 20.9 \\
negative feelings & 'interesting'; 'cute/nice bees' & 5.3 \\
value & 'fear'; 'disgusting'; & 9.4 \\
no answer & 'stinging' 'insects' & 4.4 \\
\hline
\end{tabular}

Associations with the term 'wild bee' differed between genders. Male students mentioned 'honey' or 'honeybee' more often than girls did. Female students, on the other hand, more frequently described terms that can be summarized under the category environment, such as flowers (Figure 2).

A chi-square goodness of fit test revealed that genders differed significantly in the category of 'environment' $\left(X^{2}(1)=9.0, p=0.004, N=64\right)$, while all other categories did not show statistically significant differences with regard to gender ratios ( $p$-values $>0.133$ ).

Referring to our research questions 1 and 2, it can be concluded that the majority of students did not seem to be aware of bee diversity or associate a diversity of species with the term 'wild bee', but students rather highlight the honeybee as the pollinator.

In total, 421 students participated in the identification task. The number of valid answers varies depending on the individual pictures (Table 3 ).

Answers range from $91.9 \%$ (Xylocopa violacea) up to 97.1\% (Apis mellifera). On average, participants obtained an identification score of $4.9 \pm 2.4$, indicating that less than half of the photos were identified correctly (Figure 3).

Maximal identification scores were reached by very few students whose associations were assigned to 'environment' and 'honeybee'. While a visual inspection of the ID score distribution suggests that ID scores are approximately normally distributed, results of a Kolmogorov-Smirnov test $(p<0.05)$ as well as a Shapiro-Wilk test $(p<0.05)$ revealed no normal distribution. Hence, a Mann-Whitney $U$ test was calculated to determine if there were differences in ID scores in male and female students. There was no statistically significant difference in ID scores between genders $(U=11,565.00 ; Z=778.598 ; p=0.636)$. 


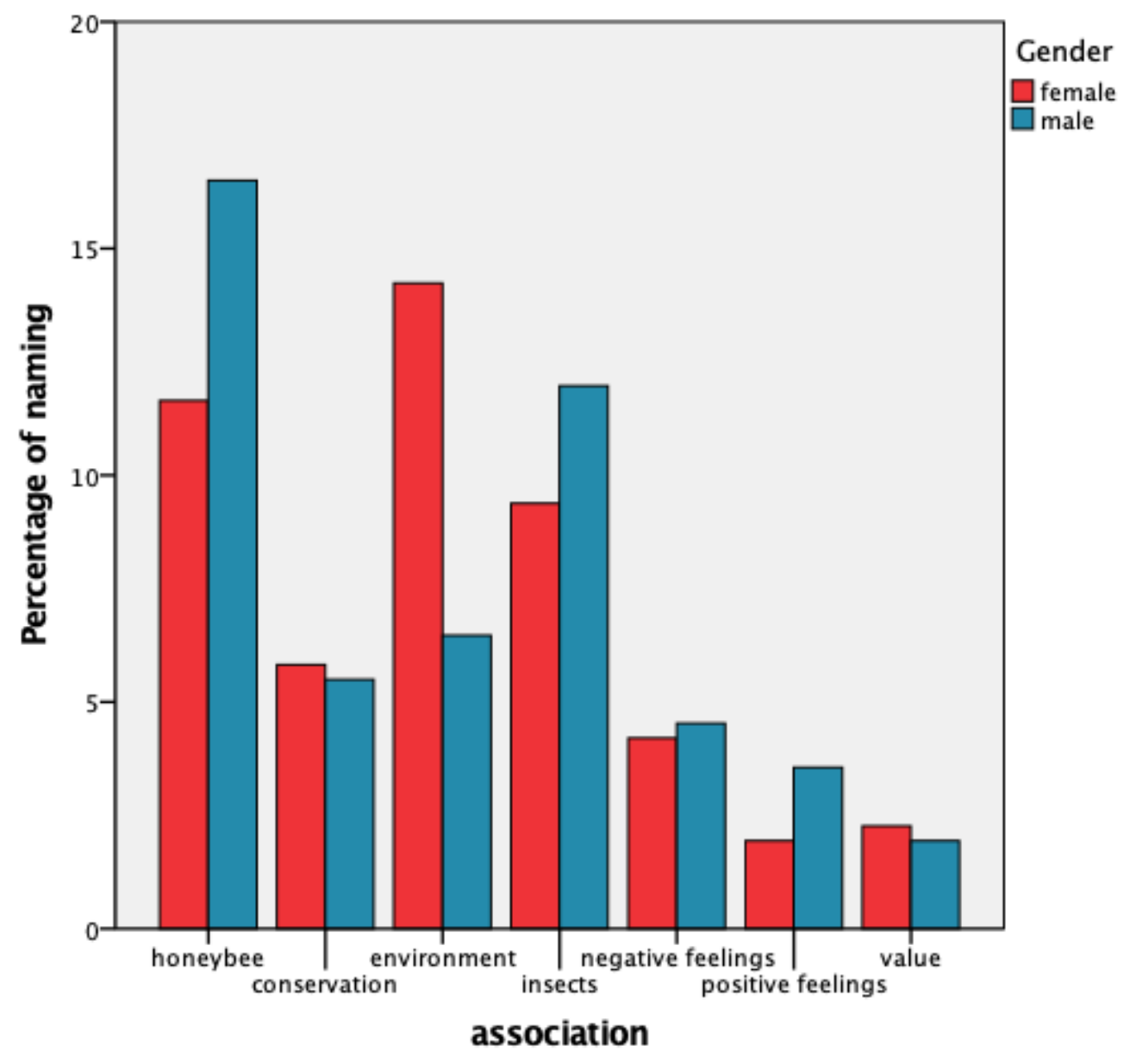

Figure 2. Percentage of the association with the term 'wild bee' of different genders. Students' answers were assigned to one of seven categories. Students without indication of gender $(\mathrm{N}=7)$ were omitted for clarity.

Table 3. Proportion of students $(\mathrm{N}=421)$ that identified the respective wild bee as such (in ascending order).

\begin{tabular}{cc}
\hline Species & Proportion of Correct Answers \\
\hline honeybee & $48.5 \%$ \\
\hline wild bees & \\
Xylocopa violacea & $30.2 \%$ \\
Bombus terrestris & $31.7 \%$ \\
Bombus lapidarius & $38.7 \%$ \\
Bombus hortorum & $39.6 \%$ \\
Bombus pratorum & $40.9 \%$ \\
Osmia bicornis & $46.3 \%$ \\
Bombus pascuorum & $52.4 \%$ \\
\hline hoverflies & $64.6 \%$ \\
\hline
\end{tabular}

The fact that students imagine a honeybee when they hear or read the word 'wild bee' is reflected in the results of the identification task in which different bee species and flies were shown. Overall, $13.8 \%$ of students could not correctly identify a single wild bee. Only $2.7 \%$ correctly detected all photos of wild bees. The proportion of students who recognized a wild bee as such differs between the depicted species (Table 3). 


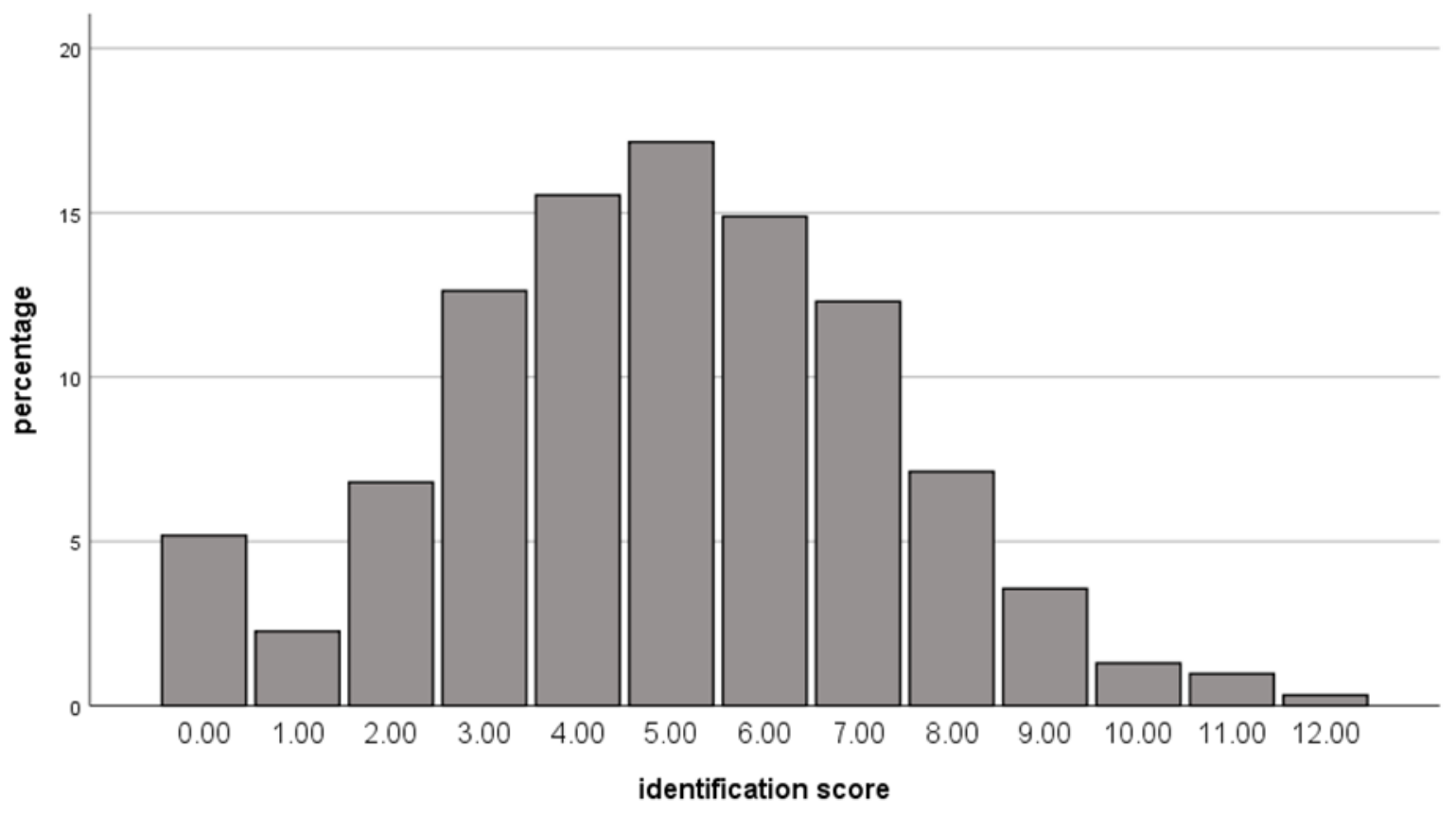

Figure 3. Distribution of Identification Scores $(\mathrm{N}=421)$.

Bumblebees were thought to be a wild bee by $40.6 \%$. The buff-tailed bumblebee (Bombus terrestris) is most often recognized as a wild bee. The other bumblebee species were classified as wild bees less frequently. The violet carpenter bee (Xylocopa violacea), which is one of the largest European bees, and the red mason bee (Osmia bicornis) were perceived as wild bees by only $38.4 \%$. Overall, a relatively high level of uncertainty is shown.

Overall, $51.5 \%$ considered a honeybee to be a wild bee. Distinguishing a honeybee from other wild bees was difficult for many students. Of the two photos showing a honeybee, $33.1 \%$ mistook the honeybee in one of the two photos for a wild bee and $33.8 \%$ did so in both photos.

Only $19.9 \%$ of students considered a hoverfly to be a wild bee, whereas $15.5 \%$ mistook both photos, and $64.6 \%$ answered correctly in this item.

\section{Discussion}

Confronted with the term 'wild bee', $28.8 \%$ of all students imagined 'honey', 'honeybee', or 'hive. Male students in particular associate these terms with it. Students are hardly aware of the fact that there is such a great diversity of appearance and lifestyle within the Apidae family. Additionally, the idea of conservation is not in many students minds (Table 2). It can be concluded that although students associate 'wild bee' with insects and honeybees in particular, they are not highly aware of their vulnerability. It is also interesting that negative feelings are more likely associated with the word 'wild bee' than positive feelings. Our results coincide with results of previous studies $[55,56]$. Results by Gerdes et al. from a study with university students show that both cognitive (e.g., fear and disgust) and emotional (e.g., danger) factors determine how arthropods are perceived. Next to spiders, which were rated highest on fear, on danger were bees and wasps, while beetles and butterflies were rated positively. As the study does not distinguish between bees and wasps, one reason for their negative ratings could be the fact that many humans experienced painful stings or are aware of the risk of being stung [56].

The difference between genders in naming terms related to the environment and nature is striking (Figure 2). While $13.97 \%$ of the female students mentioned terms related to this topic, only $6.35 \%$ of the male students did. Holstermann and Bögeholz [62], who investigated the scientific interests of German adolescents, showed that scientific interests are gender-specific. Girls are more interested in understanding natural phenomena than 
boys, while boys seem to be more interested in research, physics, and technology. General topics such as animals or humans and their interactions with their environment are equally interesting to male and female students.

Since 'wild bee' is not a scientific term, it is important that the term is introduced and used accordingly in biology or science classes as schools and their curricula are the most important sources of information for children and young adolescents. This might counteract the misconception held by many students—-that wild bees are honeybees living in the wild and are not kept by beekeepers. As mentioned above, everyday languages of most Germanic and Romanic languages use different and etymologically unrelated words for species members of the genus Bombus and other genera within the Apida family or Apinae subfamily. Additional efforts should be made to communicate that a 'Hummel' or 'bourdon' is a 'wild bee' in a biological sense, and they share the same characteristics and ecosystem functions as well as threats.

Even though $76 \%$ of the students in grade 5-7 have an idea of what the term 'wild bee' means, they do not seem to be aware of their diversity. Only $2.7 \%$ marked the correct answer for all photos. In contrast, the honeybee is often mistaken for a wild bee. Interestingly, no differences between female and male students with regard to the ID score were detected. Previous studies have shown that gender influences positive and negative attitudes dependent on which animals were investigated. In a study by Prokop and Tunnicliffe [63], girls showed more negative attitudes to dangerous or scary animals such as wolves and mice compared with boys. In contrast, girls were more positive about rabbits, and no gender differences were reported towards beetles, which could explain why our ID score does not show gender differences. The distinction between hoverfly and wild bee seems to work well, whereas the distinction between a honeybee and a wild bee seems difficult. The common carder bee (Bombus pascuorum), which resembles the familiar image of a bee due to its brownish color, is most often considered a wild bee, although it is a true bumblebee (Figure 1). Species that look quite different from honeybees are not recognized as a wild bee by students (Table 3). However, a strong visual deviation from the typical habitus of the honeybee could be helpful for conservation activities [64]. Here, it is argued that both field experience-i.e., an 'original encounter' in the language of biology educators-and the use of a non-iconic local species are well-suited for raising awareness to connect with once own environment [64]. Being familiar with the diversity of wild bees, their beauty and color in particular can be important in overcoming negative attitudes towards insects [65]. Species identification may also lead to a higher affinity towards pollinators than towards unknown species [66]. Here, it was shown that speciesrelated affinity or antipathy correlates with species knowledge. Animal species, which were identified and correctly named by study participants, received significantly higher affinity levels. At the same time, the authors stress the importance of "nature on our doorsteps" approaches in this context. Interestingly, the group of agricultural students within the study sample showed a strikingly high affinity for the buff-tailed bumblebee (Bombus terrestris). This contradicts a general low affinity for insects in general [66] and could be explained by the fact that most agricultural students might be aware of the role of bumblebees as pollinators, not only in natural environments but also in commercial agriculture where purchased bumblebee colonies are introduced into greenhouses. Thus, anchoring the diversity of pollinator species as well as their manifold roles within ecosystems in school curricula might strengthen students' attitude towards insects overall.

\section{Limitations}

As we focused on bumblebees in our educational project, the focus in the species identification task is on bumblebees. Other wild bees are underrepresented in the photo selection compared to their actual species diversity.

Moreover, study participants were recruited from a network of cooperative schools and were not selected randomly. As mentioned above, 'Don't know' was included as a response option to allow honest answers in the species identification task. Nevertheless, 
the possibility of guessing cannot be excluded completely. In a similar manner, the denial of answering individual species ID tasks can either be explained as mere ignorance or simple oversight. However, if the option 'don't know' is ticked, it can be assumed that this answer option was more likely to be chosen than guessed.

\section{SAD Is Not Always Bad-Conclusions and Implications for Education and Conservation}

The results of our study show that children and young adolescents are not aware of the diversity of bees. Thus, besides the role of both honeybees and 'wild bees' for food production and the persistence of existing habitats, knowledge of bee diversity should be focused on and implemented in biology classes. Through biological education, exploration, and interaction with nature, thinking and behavior can be influenced [67]. By experiencing nature, people can connect with insects and a willingness to care for them may emerge. This phenomenon is referred to as 'rescuing the extinction of experience', which can be achieved by expanding knowledge and raising awareness of insects in the worldview [68]. In addition, species that are known have a greater chance of being protected [69], which highlights the importance of increasing information about nature in public and also in schools. This is reflected by a statement well-known to conservationists who constantly claim that you can only protect what you know.

By educating students about 'the other bees' in their environment, they may expand their knowledge of bees above all honeybees and become aware of their importance as pollinators and beyond [15]. Moreover, only through outdoor and hands-on activities focusing on local species in their natural environment can a concern about local biodiversity be raised in schoolchildren [64]. At the same time, a willingness to protect, for example, certain local and thus locally available instead of exotic 'virtual' animals has to be developed in order to foster interest in an endangered, threatened environment [64].

One approach to motivate students to get involved in conservation activities is by letting them participate in tailored educational processes [70]. Collaborative work in scientific processes between researchers and laypeople is described as 'Citizen Science'. Here, different levels of participation can be distinguished [71]. For example, in a citizen participation activity where citizens collect observation data on wild bees, Ganzevoort and van den Born [72] indicate an increase in knowledge and appreciation of wild bees. In order to promote civic engagement in conservation contexts, a plethora of approaches and activities can be applied, both in the classroom and in out-of-school contexts. Moreover, implementing Citizen Science in school education presents a unique opportunity to reach all sections of society [73]. Providing students with possibilities to get involved with scientific research is a way to bring society and science together [74]. By participating in a Citizen Science project in the context of biology classes, students can acquire a wide variety of skills, and increase their motivation to become involved [75]. In addition, by participating in science where they contribute to world knowledge, students feel more engaged in their learning [76], increase their scientific literacy [77], and positively change their attitudes towards science [78].

In our opinion, anchoring Citizen Science in school contexts can help to overcome SAD. Our project 'Hummeln helfen! Rhein-Main' (engl. 'Helping Bumblebees within the Rhine-Main Area') starts at this point with the intention to actively involve students as they play a key role in ensuring species conservation. Using tailored teaching materials, students acquire knowledge about wild bees, learn about biodiversity, and work out various factors influencing bee and insect extinction. This is a prerequisite for successful Citizen Science activities related to bumblebee monitoring. As Falk et al. [79] could show in a study investigating two British Citizen Science projects devoted to bumblebees, both recorder accuracy and recorder success correlate with the recorders' species knowledge and identification skills. In addition, expert support as well as expert-guided training must be mandatory to obtain scientifically solid data. In line with our approach, the study recommends the use of images of the insects that are most frequently mistaken for and 
recorded as bumblebees, including e.g., the honeybee (Apis mellifera), mason bees (Genus Osmia), and hoverflies (Diptera: Syrphidae) [79]. As a consequence, experienced project staff support students to identify and quantify wild bees in their school's surroundings, develop conservation activities, and become engaged in a Citizen Science project at their school or within their neighborhood. In doing so, students will not only be citizen scientists who support ongoing research or conservation efforts but may cultivate an attitude towards wild bees and bee diversity which is referred to as environmental citizenship [80]. Environmental citizenship is a new way of thinking and acting which includes recognizing the value of environments for humans, promoting conservation, and supporting nature protection and biodiversity. Moreover, the suggested activities will focus on attitudes and values and thus counterbalance criticism of environmental or nature-based Citizen Science initiatives to only address participants' skills and knowledge [81].

In order to account for all four components of the SAD concept, further research is required. Nevertheless, our study shows that children and young adolescents are currently not aware of the diversity of bees. It can be assumed that this lack of knowledge has an impact on student attitude, attention, and relative interest. However, systematically acquired knowledge can be built to make people aware of the ecological and economic significance of bees for ecosystems. To tackle insect decline, Kawahara et al. [82] have recently suggested 'eight simple actions that individuals can take' and define two action groups, namely (1) the creation of insect-friendly habitats and (2) the implementation of activities to increase awareness and appreciation of insects [82]. In particular, the authors suggest that besides efforts to reduce negative attitudes towards insects, individuals should outreach to others as 'insect ambassadors' and get locally involved in favor of insect-friendly environmental policies [82]. All these activities and actions can broaden an individual's view of the diversity of bees in everyday life. As environmental citizens, they will not only follow ongoing research on insect decline due to drastic pesticide exposure and understand that urgent action is required [83] but will actively engage in the conservation of wild bee and insect biodiversity which play a crucial role in ecosystem stability.

Author Contributions: L.C. devised and designed the study. L.C and D.C.D. performed the research and analyzed the data. All authors have read and agreed to the published version of the manuscript.

Funding: The project 'Hummeln helfen! Rhein-Main' is funded by the Federal Agency for Nature Conservation within the German Funding Program for Supporting the National Strategy on Biological Diversity.

Institutional Review Board Statement: Not applicable.

Informed Consent Statement: Approvals of both the state school and nature authorities were granted in advance.

Data Availability Statement: Not applicable.

Acknowledgments: The authors would like to thank all teachers and students for their participation in this study. We thank Nina Meyerhöffer (Mainz, Germany) for proofreading the manuscript. Helpful comments by an anonymous reviewer are gratefully acknowledged.

Conflicts of Interest: The authors declare no conflict of interest.

\section{References}

1. Sánchez-Bayo, F.; Wyckhuys, K.A. Further evidence for a global decline of the entomofauna. Austral. Entomol. 2021, 60, 9-26. [CrossRef]

2. Wagner, D.L.; Grames, E.M.; Forister, M.L.; Berenbaum, M.R.; Stopak, D. Insect decline in the Anthropocene: Death by a thousand cuts. Proc. Natl. Acad. Sci. USA 2021, 118, e2023989118. [CrossRef] [PubMed]

3. Sánchez-Bayo, F.; Wyckhuys, K.A. Worldwide decline of the entomofauna: A review of its drivers. Biol. Conserv. 2019, 232, 8-27. [CrossRef]

4. Althaus, S.L.; Berenbaum, M.R.; Jordan, J.; Shalmon, D.A. No buzz for bees: Media coverage of pollinator decline. Proc. Natl. Acad. Sci. USA 2021, 118, e2002552117. [CrossRef] [PubMed] 
5. Hallmann, C.A.; Sorg, M.; Jongejans, E.; Siepel, H.; Hofland, N.; Schwan, H.; Stenmans, W.; Müller, A.; Sumser, H.; Hörren, T.; et al. More than 75 percent decline over 27 years in total flying insect biomass in protected areas. PLoS ONE 2017, 12, e0185809. [CrossRef]

6. Hartmann, H.; Haensel, M.; Riebl, R.; Lohse, E.J.; Koellner, T. Volksbegehren Artenvielfalt: Gesetzesänderungen können auch Ökosystemdienstleistungen in Bayerns Agrarlandschaften stärken. GAIA-Ecol. Perspect. Sci. Soc. 2021, 30, 106-113. [CrossRef]

7. Klein, A.-M.; Vaissière, B.E.; Cane, J.H.; Steffan-Dewenter, I.; Cunningham, S.A.; Kremen, C.; Tscharntke, T. Importance of pollinators in changing landscapes for world crops. Proc. R. Soc. B Biol. Sci. 2007, 274, 303-313. [CrossRef]

8. Leonhardt, S.D.; Gallai, N.; Garibaldi, L.A.; Kuhlmann, M.; Klein, A.-M. Economic gain, stability of pollination and bee diversity decrease from southern to northern Europe. Basic Appl. Ecol. 2013, 14, 461-471. [CrossRef]

9. Goulson, D.; Nicholls, E.; Botías, C.; Rotheray, E.L. Bee declines driven by combined stress from parasites, pesticides, and lack of flowers. Science 2015, 347, 1255957. [CrossRef]

10. Papanikolaou, A.D.; Kühn, I.; Frenzel, M.; Kuhlmann, M.; Poschlod, P.; Potts, S.G.; Roberts, S.P.M.; Schweiger, O. Wild bee and floral diversity covary in response to the direct and indirect impacts of land use. Ecosphere 2017, 8, e02008. [CrossRef]

11. Ritchie, A.D.; Ruppel, R.; Jha, S. Generalist Behavior Describes Pollen Foraging for Perceived Oligolectic and Polylectic Bees. Environ. Entomol. 2016, 45, 909-919. [CrossRef]

12. Amiet, F; Krebs, A.; Müller, A. Bienen Mitteleuropas. Gattungen, Lebensweise, Beobachtung. 3. Auflage; Haupt Verlag: Bern, Switzerland, 2019.

13. Garantonakis, N.; Varikou, K.; Birouraki, A.; Edwards, M.; Kalliakaki, V.; Andrinopoulos, F. Comparing the pollination services of honey bees and wild bees in a watermelon field. Sci. Hortic. 2016, 204, 138-144. [CrossRef]

14. Ollerton, J. Pollinators \& Pollination: Nature and Society; Pelagic Publishing: Exeter, UK, 2021.

15. Bhattacharyya, M.; Acharya, S.K.R.; Chakraborty, S.K. Pollinators Unknown: People's Perception of Native Bees in an Agrarian District of West Bengal, India, and Its Implication in Conservation. Trop. Conserv. Sci. 2017, 10, 1940082917725440. [CrossRef]

16. Winfree, R.; Bartomeus, I.; Cariveau, D.P. Native Pollinators in Anthropogenic Habitats. Annu. Rev. Ecol. Evol. Syst. 2011, 42, 1-22. [CrossRef]

17. Smith, T.J.; Saunders, M.E. Honey bees: The queens of mass media, despite minority rule among insect pollinators. Insect Conserv. Divers. 2016, 9, 384-390. [CrossRef]

18. Gallai, N.; Salles, J.-M.; Settele, J.; Vaissière, B.E. Economic valuation of the vulnerability of world agriculture confronted with pollinator decline. Ecol. Econ. 2009, 68, 810-821. [CrossRef]

19. Potts, S.G.; Biesmeijer, J.C.; Kremen, C.; Neumann, P.; Schweiger, O.; Kunin, W.E. Global pollinator declines: Trends, impacts and drivers. Trends Ecol. Evol. 2010, 25, 345-353. [CrossRef]

20. Breeze, T.D.; Bailey, A.P.; Balcombe, K.G.; Potts, S.G. Pollination services in the UK: How important are honeybees? Agric. Ecosyst. Environ. 2011, 142, 137-143. [CrossRef]

21. Garibaldi, L.A.; Steffan-Dewenter, I.; Winfree, R.; Aizen, M.A.; Bommarco, R.; Cunningham, S.A.; Kremen, C.; Carvalheiro, L.G.; Harder, L.D.; Afik, O.; et al. Wild pollinators enhance fruit set of crops regardless of honey bee abundance. Science 2013, 339, 1608-1611. [CrossRef]

22. Westrich, P.; Frommer, U.; Mandery, K.; Riemann, H.; Ruhnke, H.; Saure, C.; Voith, J. Rote Liste und Gesamtartenliste der Bienen (Hymenoptera: Apidae) Deutschlands. Fass. Febr. 2011, 70, 373-416.

23. Bogusch, P.; Bláhová, E.; Horák, J. Pollen specialists are more endangered than non-specialised bees even though they collect pollen on flowers of non-endangered plants. Anthr. Plant-Interact. 2020, 14, 759-769. [CrossRef]

24. Falk, S.J. Field Guide to the Bees of Great Britain and Ireland. Unter Mitarbeit von Richard Lewington, Reprinted with Corrections; Bloomsbury Wildlife Guides: London, UK, 2006.

25. Wissenschaftlicher Rat der Dudenredaktion (Hg.). Duden. Das Grosse Wörterbuch der Deutschen Sprache in 10 Bänden. Band 10. Band 4. 3. Aufl.; Dudenverlag: Mannheim, Germany, 1999.

26. Wahrig-Burfeind, R. Brockhaus Wahrig Deutsches Wörterbuch. Mit Einem Lexikon der Sprachlehre. 9. Vollständig Neu Bearbeitete und Aktualisierte Aufl.; Wissenmedia: Gütersloh, Germany, 2011.

27. Kluge, F.; Seebold, E. Etymologisches Wörterbuch der Deutschen Sprache. 25. Durchgesehene und Erw. Aufl.; De Gruyter: Berlin, Germany; Boston, MA, USA, 2011.

28. Westrich, P. Wildbienen: Die anderen Bienen. 5. Aufl.; Pfeil: München, Germany, 2015.

29. Westrich, P. Die Wildbienen Deutschlands. 2. Aufl.; Ulmer, E., Ed.; Verlag Eugen Ulmer: Stuttgart, Germany, 2019.

30. Wandersee, J.H.; Schussler, E.E. Toward a theory of plant blindness. Plant Sci. Bull. 2001, 47, $2-9$.

31. Oliveira, W.; Silva, J.L.S.; Porto, R.; Cruz-Neto, O.; Tabarelli, M.; Viana, B.F.; Peres, C.A. Plant and Pollination Blindness: Risky Business for Human Food Security. BioScience 2019, 70, 109-110. [CrossRef]

32. Parsley, K.M. Plant awareness disparity: A case for renaming plant blindness. Plants People Planet 2020, 2, 598-601. [CrossRef]

33. Schussler, E.E.; Olzak, L.A. It's not easy being green: Student recall of plant and animal images. J. Biol. Educ. 2008, 42, 112-119. [CrossRef]

34. Feldman, J. What is a visual object? Trends Cogn. Sci. 2003, 7, 252-256. [CrossRef]

35. Knapp, S. Are humans really blind to plants? Plants People Planet 2019, 1, 164-168. [CrossRef]

36. Kellert, S.R. Attitudes, Knowledge, and Behavior toward Wildlife among the Industrial Superpowers: United States, Japan, and Germany. J. Soc. Issues 1993, 49, 53-69. [CrossRef]

37. Bjerke, T.; Østdahl, T. Animal-related attitudes and activities in an urban population. Anthrozoös 2004, 17, 109-129. [CrossRef] 
38. Retzlaff-Fürst, C. Das Lebende Tier im Schülerurteil. Bodenlebewesen im Biologieunterricht-Eine Empirische Studie. Didaktik in Forschung und Praxis, Bd. 40; Kovač: Hamburg, Germany, 2008.

39. Urhahne, D.; Jeschke, J.; Krombaß, A.; Harms, U. Die Validierung von Fragebogenerhebungen zum Interesse an Tieren und Pflanzen durch computergestützte Messdaten. Z. Pädagogische Psychol. 2004, 18, 213-219. [CrossRef]

40. Lindemann-Matthies, P.; Bose, E. How Many Species Are There? Public Understanding and Awareness of Biodiversity in Switzerland. Hum. Ecol. 2008, 36, 731-742. [CrossRef]

41. Fančovičová, J.; Prokop, P. Plants have a chance: Outdoor educational programmes alter students' knowledge and attitudes towards plants. Environ. Educ. Res. 2011, 17, 537-551. [CrossRef]

42. Scott, G.W.; Goulder, R.; Wheeler, P.; Scott, L.J.; Tobin, M.L.; Marsham, S. The Value of Fieldwork in Life and Environmental Sciences in the Context of Higher Education: A Case Study in Learning about Biodiversity. J. Sci. Educ. Technol. 2012, 21, 11-21. [CrossRef]

43. Silveira, F.A.O.; Ordóñez-Parra, C.A.; Moura, L.C.; Schmidt, I.B.; Andersen, A.N.; Bond, W.; Buisson, E.; Durigan, G.; Fidelis, A.; Oliveira, R.S.; et al. Biome Awareness Disparity is BAD for tropical ecosystem conservation and restoration. J. Appl. Ecol. 2021, 00, 1-9. [CrossRef]

44. Horsley, S.; Hohbein, R.; Morrow, K.; Green, G.T. What's in a name? A content analysis of environmental NGOs' use of “iconic species" in press releases. Biodivers. Conserv. 2020, 29, 2711-2728. [CrossRef]

45. Macdonald, E.A.; Hinks, A.; Weiss, D.J.; Dickman, A.; Burnham, D.; Sandom, C.J.; Malhi, Y.; Macdonald, D.W. Identifying ambassador species for conservation marketing. Glob. Ecol. Conserv. 2017, 12, 204-214. [CrossRef]

46. Ministerium für Bildung, Wissenschaft und Weiterbildung und Kultur. Lehrpläne für die Naturwissenschaftlichen Fächer Für die Weiterführenden Schulen in Rheinland-Pfalz. Biologie, Chemie, Physik. Klassenstufen 7 bis 9/10; Ministerium für Bildung, Wissenschaft und Weiterbildung und Kultur: Mainz, Germany, 2014.

47. Berck, K.-H.; Graf, D. Biologiedidaktik. Grundlagen und Methoden. Unter Mitarbeit von Anke Fischer und Melek Yaman. 5. Aktualisierte Auflage; Quelle \& Meyer: Wiebelsheim, Germany, 2018.

48. Bickel, H.; Claus, R.; Frank, R.; Haala, G.; Lüdecke, M.; Wichert, G.; Zohren, D. Natura. Biologie für Gymnasien. 7. Bis 10 Schuljah; Ernst Klett: Stuttgart, Germany, 2002.

49. Dobers, J.; Freundner-Huneke, I.; Schulu, S.; Zeeb, A. Erlebnis Biologie. Gesamtband ab 7. Schuljahr; Schroedel: Braunschweig, Germany, 2010.

50. Hausfeld, R.; Schulenberg, W.; Bioskop, S.I. Gymnasium Rheinland-Palz, Druck A; Westermann: Braunschweig, Germany, 2016.

51. Batke, S.P.; Dallimore, T.; Bostock, J. Understanding Plant Blindness-Students' Inherent Interest of Plants in Higher Education. J. Plant Sci. 2020, 8, 98-105. [CrossRef]

52. Prokop, P.; Tunnicliffe, S.D. “Disgusting” Animals: Primary School Children's Attitudes and Myths of Bats and Spiders. Eurasia J. Math. Sci. Technol. Educ. 2008, 4, 87-97. [CrossRef]

53. Kellert, S.R. Values and Perceptions of Invertebrates. Conserv. Biol. 1993, 7, 845-855. [CrossRef]

54. Schönfelder, M.L.; Bogner, F.X. Individual perception of bees: Between perceived danger and willingness to protect. PLoS ONE 2017, 12, e0180168. [CrossRef]

55. Arrindell, W.A. Phobic dimensions: IV. The structure of animal fears. Behav. Res. Ther. 2000, 38, 509-530. [CrossRef]

56. Gerdes, A.B.M.; Uhl, G.; Alpers, G.W. Spiders are special: Fear and disgust evoked by pictures of arthropods. Evol. Hum. Behav. 2009, 30, 66-73. [CrossRef]

57. Sieg, A.-K.; Teibtner, R.; Dreesmann, D. Don't Know Much about Bumblebees? A Study about Secondary School Students' Knowledge and Attitude Shows Educational Demand. Insects 2018, 9, 57. [CrossRef]

58. Sieg, A.-K.; Dreesmann, D. Promoting Pro-Environmental BEEhavior in School. Factors Leading to Eco-Friendly Student Action. Sustainability 2021, 13, 6598. [CrossRef]

59. Bellmann, H. Der Kosmos Insektenführer; Franckh-Kosmos: Stuttgart, Germany, 2018.

60. Chinery, M. Parey's Buch der Insekten. In Über 2000 Insekten Europas; Franckh-Kosmos: Stuttgart, Germany, 2012.

61. Field, A. Discovering Statistics Using IBM SPSS Statistics, 5th ed.; SAGE Publications: Los Angeles, CA, USA; London, UK; New Delhi, India; Singapore; Washington, DC, USA; Melbourne, Australia, 2018.

62. Holstermann, N.; Bögeholz, S. Interesse von Jungen und Mädchen an naturwissenschaftlichen Themen am Ende der Sekundarstufe I. Z. Didakt. Nat. 2007, 13, 71-86.

63. Prokop, P.; Tunnicliffe, S.D. Effects of having pets at home on children's attitudes toward popular and unpopular animals. Anthrozoös 2010, 23, 21-35. [CrossRef]

64. Ballouard, J.-M.; Brischoux, F.; Bonnet, X. Children prioritize virtual exotic biodiversity over local biodiversity. PLoS ONE 2011, 6, e23152. [CrossRef]

65. Schlegel, J.; Breuer, G.; Rupf, R. Local Insects as Flagship Species to Promote Nature Conservation? A Survey among Primary School Children on Their Attitudes toward Invertebrates. Anthrozoös 2015, 28, 229-245. [CrossRef]

66. Schlegel, J.; Rupf, R. Attitudes towards potential animal flagship species in nature conservation: A survey among students of different educational institutions. J. Nat. Conserv. 2010, 18, 278-290. [CrossRef]

67. Kahn, P.H., Jr. Children's affiliations with nature: Structure, development, and the problem of environmental generational amnesia. In Children and Nature: Psychological, Sociocultural, and Evolutionary Investigations; Kahn, P.H., Jr., Kellert, S.R., Eds.; MIT: Cambridge, UK, 2002; pp. 93-116.

68. Samways, M.J. Rescuing the extinction of experience. Biodivers. Conserv. 2007, 16, 1995-1997. [CrossRef] 
69. Swiss Biodiversity Forum (Hrsg.). Biodiversität in der Schweiz-Zustand, Erhaltung, Perspektiven; Haupt Verlag: Bern, Switzerland, 2004.

70. Cho, Y.; Lee, D. 'Love honey, hate honey bees': Reviving biophilia of elementary school students through environmental education program. Environ. Educ. Res. 2018, 24, 445-460. [CrossRef]

71. Bonn, A.; Richter, A.; Vohland, K.; Pettibone, L.; Brandt, M.; Feldmann, R.; Goebel, C.; Grefe, C.; Hecker, S.; Henken, L.; et al. Grünbuch Citizen Science Strategie 2020 für Deutschland; Helmholtz Zentrum für Umweltforschung (UFZ), Deutsches Zentrum für integrative Biodiversitätsforschung (iDiv), Halle-Jena-Leipzig, Museum für Naturkunde Berlin, Leibniz- Institut für Evolutionsund Biodiversitätsforschung (MfN), Berlin-brandenburgisches Institut für Biodiversitätsforschung (BBIB): Berlin, Germany, 2016.

72. Ganzevoort, W.; Van Den Born, R.J.G. Counting Bees: Learning Outcomes from Participation in the Dutch National Bee Survey. Sustainability 2021, 13, 4703. [CrossRef]

73. Ruiz-Mallén, I.; Riboli-Sasco, L.; Ribrault, C.; Heras, M.; Laguna, D.; Perié, L. Citizen Science. Sci. Commun. 2016, 38, 523-534. [CrossRef]

74. Vohland, K.; Land-Zandstra, A.; Ceccaroni, L.; Lemmens, R.; Perelló, J.; Samson, R.P.M.; Wagenknecht, K. The Science of Citizen Science; Springer International Publishing: Berlin/Heidelberg, Germany, 2021. [CrossRef]

75. Kreuzer, P.; Dreesmann, D. Museum behind the scenes-an inquiry-based learning unit with biological collections in the classroom. J. Biol. Educ. 2016, 51, 261-272. [CrossRef]

76. Harlin, J.; Kloetzer, L.; Patton, D.; Leonhard, C.; Leysin American School High School Students. Turning students into citizen scientists. In Citizen Science: Innovation in Open Science, Society and Policy; Hecker, S., Haklay, M., Bowser, A., Makuch, Z., Vogel, J., Bonn, A., Eds.; UCL Press: London, UK, 2018. [CrossRef]

77. Zoellick, B.; Nelson, S.J.; Schauffler, M. Participatory science and education: Bringing both views into focus. Front. Ecol. Environ. 2012, 10, 310-313. [CrossRef]

78. Vitone, T.; Stofer, K.; Steininger, M.S.; Hulcr, J.; Dunn, R.; Lucky, A. School of Ants goes to college: Integrating citizen science into the general education classroom increases engagement with science. J. Sci. Commun. 2016, 15, A03. [CrossRef]

79. Falk, S.; Foster, G.; Comont, R.; Conroy, J.; Bostock, H.; Salisbury, A.; Kilbey, D.; Bennett, J.; Smith, B. Evaluating the ability of citizen scientists to identify bumblebee (Bombus) species. PLoS ONE 2019, 14, e0218614. [CrossRef]

80. Jørgensen, F.A.; Jørgensen, D. Citizen science for environmental citizenship. Conserv. Biol. 2021, 35, 1344. [CrossRef]

81. Adamou, A.; Georgiou, Y.; Paraskeva-Hadjichambi, D.; Hadjichambis, A.C. Environmental Citizen Science Initiatives as a Springboard towards the Education for Environmental Citizenship: A Systematic Literature Review of Empirical Research. Sustainability 2021, 13, 13692. [CrossRef]

82. Kawahara, A.Y.; Reeves, L.E.; Barber, J.A.; Black, S.H. Eight simple actions that individuals can take to save insects from global declines. Proc. Natl. Acad. Sci. USA 2021, 118, e2002547117. [CrossRef]

83. Brühl, C.A.; Bakanov, N.; Köthe, S.; Eichler, L.; Sorg, M.; Hörren, T.; Mühlethaler, R.; Meinel, G.; Lehmann, G.U.C. Direct pesticide exposure of insects in nature conservation areas in Germany. Sci. Rep. 2021, 11, 24144. [CrossRef] 